\title{
Effects of Postharvest Onion Curing Parameters on Enterobacter Bulb Decay in Storage
}

\author{
B. K. Schroeder, Washington State University, Pullman 99164; and L. J. du Toit, Washington State University, \\ Mount Vernon NWREC, Mount Vernon 98273
}

\begin{abstract}
Schroeder, B. K., and du Toit, L. J. 2010. Effects of postharvest onion curing parameters on Enterobacter bulb decay in storage. Plant Dis. 94:1425-1430.
\end{abstract}

Enterobacter bulb decay is a recently described storage disease of onion (Allium cepa) bulbs caused by Enterobacter cloacae. The disease is generally considered minor but, on occasion, can cause significant losses for onion producers. The impact of postharvest curing temperature and duration on Enterobacter bulb decay of onion was evaluated by inoculating bulbs of the cultivars Redwing and Vaquero with E. cloacae after harvest, curing the bulbs at $25,30,35$, or $40^{\circ} \mathrm{C}$ for 2 or 14 days, and storing the bulbs at $5^{\circ} \mathrm{C}$ for 1,2 , or 3 months. Noninoculated bulbs and bulbs injected with sterile water served as control treatments. The trial was completed using bulbs harvested from commercial onion crops grown in the semi-arid Columbia Basin of central Washington in each of 2008-09 (center-pivot irrigated crop) and 2009-10 (drip irrigated crop). Severity of bulb rot was assessed by cutting each bulb down the center from the neck to the basal plate, and rating the percentage of cut surface area with bacterial rot symptoms. Bulb rot severity was negligible for noninoculated bulbs (mean of $0.3 \%$ in the 2008-09 storage trial and $1.0 \%$ in the 2009-10 storage trial) and bulbs injected with water $(0.8 \%$ in the $2008-09$ trial and $1.3 \%$ in the 2009-10 trial) compared to bulbs inoculated with E. cloacae (15.3\% in 2008-09 and $23.3 \%$ in 2009-10). Severity of Enterobacter bulb decay was affected significantly $(P<0.05)$ by season (trial), cultivar, curing temperature, curing duration, and storage duration, with significant interactions among these factors. Enterobacter bulb decay was significantly more severe for bulbs cured at $40^{\circ} \mathrm{C}$ than for bulbs cured at 25,30 , or $35^{\circ} \mathrm{C}$. This effect was even greater when bulbs were cured for 14 days versus 2 days prior to cold storage, and in bulbs stored for 2 or 3 months after curing compared to bulbs stored for 1 month. The increase in bulb rot severity caused by curing bulbs at $40^{\circ} \mathrm{C}$ for 14 days compared to lower temperatures and shorter durations was greater for Vaquero than Redwing, particularly in the 2008-09 trial. The results suggest that curing temperatures $\leq 35^{\circ} \mathrm{C}$ should significantly reduce the risk of Enterobacter bulb decay in storage for these cultivars. If higher curing temperatures are used in order to dry onion necks for long-term storage and reduce the risk of fungal diseases such as neck rot (caused by Botrytis spp.), a shorter curing duration may be necessary to minimize the risk of Enterobacter bulb decay in storage.

In the United States, storage onions $(A l$ lium cepa L.) are produced on $>44,515$ ha annually, resulting in $>\$ 900$ million in farm receipts (1). Storage onion crops in the western United States comprise approximately $66 \%$ of the onion production in this country (1). Onion bulb storage rots typically develop after the bulbs have been harvested, cured, and placed in storage (21). Although a low level of onion bulb rot $(<1 \%)$ is not uncommon for most storage crops, greater amounts of bulb rot can occur and result in tremendous economic losses for growers and packers (14). Often,

Corresponding author: Brenda K. Schroeder E-mail: bschroeder@wsu.edu

* The $\boldsymbol{e}$-Xtra logo stands for "electronic extra" and indicates that Figure 1 appears in color in the online edition.

Accepted for publication 23 June 2010.

doi:10.1094/PDIS-06-10-0457

(C) 2010 The American Phytopathological Society reported that $16 \%$ of onion shipments into New York State that were inspected annually from 1972 to 1984 had symptoms of storage rots. Bacterial pathogens were associated with $>50 \%$ of the symptomatic shipments, of which $35 \%$ exhibited unacceptable levels of storage rot $(>2 \%)$. Each shipment with $>2 \%$ rot translated to $100 \%$ loss for the producer because of failure to meet United States No. 1 grade standards. Although the current prevalence and incidence of onion storage rots in the United States is not well documented, empirical evidence indicates that onion growers and packers still suffer substantial losses to bacterial storage rot pathogens.

At least 11 bacterial plant pathogens have been reported to cause onion bulb rots in storage (21). Enterobacter cloacae (Jordan) Hormaeche \& Edwards causes Enterobacter bulb decay of onion, which has been documented in Australia (7), California (2), Colorado (22), and Washington (17). The disease is characterized by discoloration and softening of some internal fleshy scales of the bulb during storage (8). Decay usually starts at the neck of the bulb and progresses toward the basal plate. Unlike symptoms caused by some other bacterial bulb rot pathogens such as Dickeya chrysanthemi or Pectobacterium carotovorum subsp. carotovorum (21), scales infected with E. cloacae tend to maintain integrity, and the rot usually does not progress between adjacent scales (Fig. 1).

E. cloacae is a ubiquitous, facultatively anaerobic, rod-shaped bacterium com-
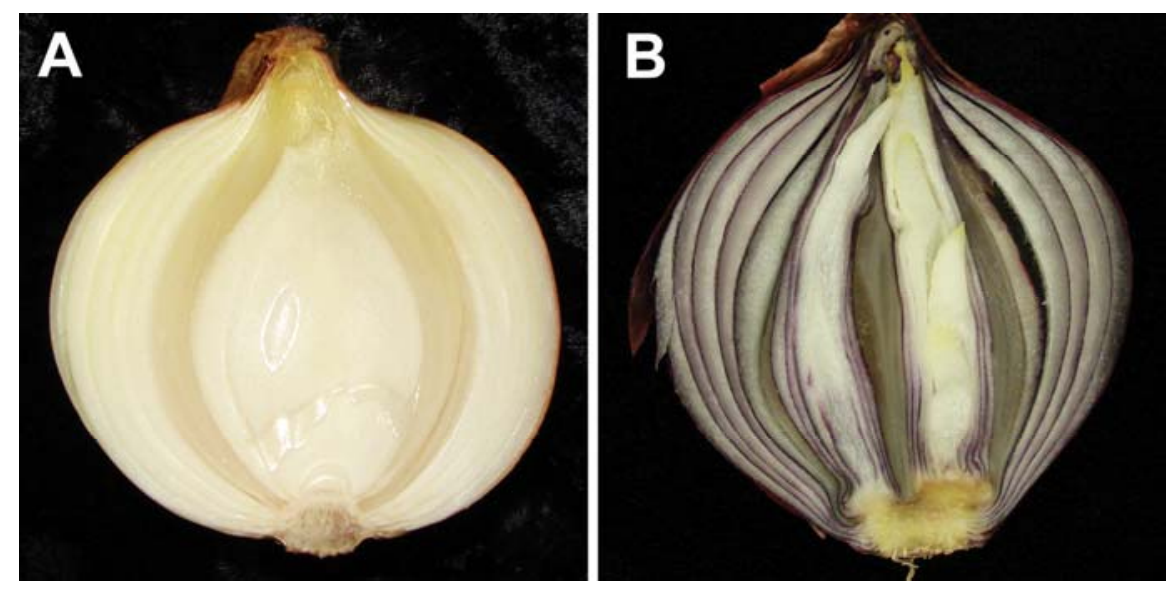

Fig. 1. Symptoms of Enterobacter bulb decay on the onion cultivars Vaquero (A) and Redwing (B) following injection with Enterobacter cloacae, curing the bulbs at $30^{\circ} \mathrm{C}$ for 14 days, and storing the bulbs for 2 months at $5^{\circ} \mathrm{C}$. Each bulb was then cut down the center from the neck to the basal plate through the injection site on the shoulder of the bulb. 
monly associated with humans, plants, and insects, as well as water, soil, and sewage $(6,9,10,15)$. The bacterium has been identified as a postharvest pathogen of various crops (11-13), but little is known about the association of E. cloacae with onion plants or bulbs and the specific host-pathogen interactions that lead to storage rot. $E$. cloacae is a common soil inhabitant (15), so infested soil could serve as a reservoir of the pathogen. The bacterium is thought to colonize onion plants in the field and then persist as latent infections when onion bulbs are placed in storage (21). Onion bulbs removed from the field at harvest have been reported to be infected by $E$. cloacae (2; Schroeder and du Toit, unpublished), but currently there is no evidence of preharvest symptoms of infection of onion plants by E. cloacae.

Environmental conditions and cultural practices in onion crops that promote development of Enterobacter bulb decay in storage remain unknown. The occurrence of rainfall just prior to harvest of an onion crop might potentially affect Enterobacter bulb decay in storage (21), but the impact of other factors such as overhead irrigation, water source (surface or recycled irrigation water), and use of manures as fertilizers have not been evaluated $(14,21)$. Cultural practices such as harvest of bulbs at appropriate crop maturity, the amount of moisture present in the necks at harvest, "topping" (a mechanical or manual process of removing the leaves above the necks prior to, or during, harvest), and prevention of wounding or bruising of bulbs during harvest and sorting can influence development of onion storage rots caused by Pseudomonas marginalis, Burkholderia gladioli pv. alliicola, Pseudomonas viridiflava, and $P$. carotovorum subsp. carotovorum (24-27). However, the impact of these factors on development of Enterobacter bulb decay remain to be determined. Bishop and Davis (2) reported E. cloacae infection of mature onion bulbs following periods of very high air temperatures during the growing season $\left(40\right.$ to $45^{\circ} \mathrm{C}$ ), which suggests that air temperature in the latter part of the field season may influence development of Enterobacter bulb decay.

Field curing and/or postharvest curing is critical for preparing onion bulbs for longterm storage (3). This results in reduced moisture loss during storage, translating to less shrinkage of the bulbs and restriction of the movement of fungal pathogens from the neck into the fleshy bulb scales (3). Field curing in the semi-arid conditions of the western United States entails terminating irrigation at the end of the season and undercutting onion plants at 70 to $90 \%$ "tops down" (leaves fallen over after the neck has dried). The bulbs are then topped to remove the leaves, and the necks continue to dry in the field. In areas such as the Pacific Northwest, field curing is typi- cally followed by postharvest curing in storage facilities (14). Postharvest curing involves movement of either ambient air (24 to $27^{\circ} \mathrm{C}$ or higher, depending on weather conditions) through the storage facility for 2 to 3 weeks, or heated air (29 to $35^{\circ} \mathrm{C}$ or higher) for 2 days or longer. Once the relative humidity of air exiting the storage facility is $<70 \%$, the storage temperature is then decreased 1 to $5^{\circ} \mathrm{C}$ daily until the temperature reaches approximately 3 to $5^{\circ} \mathrm{C}(3,14)$. However, the higher curing temperatures sometimes used in commercial storage facilities are also favorable for growth of some bacterial plant pathogens such as $B$. gladioli pv. alliicola, B. cepacia, and E. cloacae (21). The objectives of this study were to assess how postharvest curing temperature, curing duration, and duration of storage of onion bulbs influence severity of Enterobacter bulb decay. The knowledge generated by this study is expected to help onion stakeholders optimize postharvest bulb curing parameters as part of an integrated strategy to minimize losses to Enterobacter bulb decay.

\section{MATERIALS AND METHODS}

Experimental design and source of onion bulbs. The study was set up as a randomized complete block design with a factorial combination of two onion cultivars (Redwing and Vaquero) representing typical red and yellow storage cultivars grown in the Pacific Northwest region of the United States, three inoculation treatments (E. cloacae, water, and noninoculated), four curing temperatures $(25,30$, 35 , and $40^{\circ} \mathrm{C}$ ), two curing durations ( 2 and 14 days), and three storage durations $(1,2$, and 3 months). Four replicates of five onion bulbs were used for each treatment combination. The trial was carried out in the 2008-09 storage season and repeated in the 2009-10 storage season. Redwing and Vaquero bulbs used in this study were harvested in 2008 and 2009 from commercial onion crops grown in the semi-arid Columbia Basin of central Washington using production practices typical for this region (14). The bulbs ranged from 5.0 to $7.5 \mathrm{~cm}$ in diameter, and were harvested manually after each crop had been topped mechanically. The 2008 crop of each cultivar was grown using center-pivot irrigation, and the 2009 crop of each cultivar was produced by a different growercooperator using drip irrigation.

Onion bulb inoculations. E. cloacae strain ECWSU1 (19) was grown overnight in $5 \mathrm{ml}$ of nutrient broth $(23)$ at $28^{\circ} \mathrm{C}$ with agitation. A $0.5 \mathrm{ml}$ aliquot of the culture was then added to $250 \mathrm{ml}$ of nutrient broth and incubated overnight at $28^{\circ} \mathrm{C}$ with agitation. Cells were harvested by centrifugation $(48,800 \times g$ for $10 \mathrm{~min})$, washed with sterile distilled water, and resuspended in sterile distilled water to an optical density $\left(\mathrm{OD}_{600}\right)$ of 0.3 (approximately $1 \times 10^{8}$
$\mathrm{CFU} / \mathrm{ml})$. The inoculum was then dispensed into sterile test tubes. Each bulb was inoculated at the shoulder as described by Schroeder et al. (19). A separate test tube of inoculum and a new, sterile syringe were used for each replicate of five onion bulbs. Bulbs were similarly injected with sterile water for one of the control treatments, and noninoculated bulbs served as the second control treatment to assess the incidence of natural infection of each commercial bulb lot by E. cloacae.

Bulb curing and storage. After inoculation, four replicate sets of 15 onion bulbs for each cultivar and inoculation treatment were placed in nylon mesh onion bags in incubators set at $25,30,35$, or $40^{\circ} \mathrm{C}$. The bulbs were cured for 2 or 14 days with a fan circulating air within each chamber. The temperature in each incubator was then reduced by $2.5^{\circ} \mathrm{C}$ daily to reach $5^{\circ} \mathrm{C}$. The bulbs were stored at $5^{\circ} \mathrm{C}$ for 1,2 , or 3 months. After the appropriate duration of storage, five bulbs were removed from each replicate bag and evaluated for severity of Enterobacter bulb decay. Each onion bulb was sliced through the center of the inoculation site from the neck to the basal plate, and the cut surface area of the fleshy scales was rated visually for severity of Enterobacter bulb decay (percentage of the surface area of the fleshy scales showing symptoms typical of this disease) (18-20). A low incidence of bulbs ( 1 to 5\%) showed symptoms characteristic of other storage rots (e.g., neck rot caused by Botrytis aclada and B. allii, black mold caused by Aspergillus niger, Fusarium basal rot caused by Fusarium oxysporum f. sp. cepae, and yeast soft rot caused by Kluyveromyces marxianus var. marxianus) (21), which confounded the ability to rate severity of Enterobacter bulb decay. These bulbs were treated as missing data to avoid confusing Enterobacter bulb decay with other storage rots.

Statistical analyses. Bulb rot severity ratings were subjected to analyses of variance (ANOVA) using SAS Version 9.2 (SAS Institute, Cary, NC), with trial and replication as random effects, and inoculation treatment, cultivar, curing temperature, curing duration, and duration of storage as fixed effects. In each trial, bulb rot severity ratings for the two control treatments were extremely low compared to ratings for bulbs inoculated with E. cloacae (Table 1). Therefore, the two control treatments were not included in the ANOVA to avoid extremely heterogeneous variances. Data for the inoculated bulbs were subjected to log or square root transformations (Table 2) because of heterogeneous variances and/or non-normal distribution of residuals. Results were analyzed separately for each trial because of a significant trial main effect and significant interactions of trial with other factors in the ANOVA. Mean bulb rot severity ratings were compared using Fisher's pro- 
tected least significant difference (LSD). Pearson's correlation coefficients were calculated overall and by cultivar for mean bulb rot severity ratings in the 2008-09 trial versus the 2009-10 trial.

\section{RESULTS}

Inoculation of onion bulbs with $E$. cloacae. Inoculation of E. cloacae strain ECWSU1 into onion bulbs of the cultivars Redwing and Vaquero increased the incidence and severity of bacterial storage rot in each trial compared to noninoculated bulbs or bulbs injected with sterile water, regardless of postharvest curing parameters and duration of storage (Table 1). E. cloacae caused light brown necrosis of the inner fleshy scales that was typical of Enterobacter bulb decay (Fig. 1) $(8,19)$. Symptoms developed primarily in the upper half of each inoculated bulb with necrosis spreading toward the basal plate.
Severity of bulb rot averaged $15.3 \pm 0.6 \%$ (mean \pm standard error) and $23.3 \pm 0.8 \%$ for bulbs inoculated with E. cloacae in the 2008-09 and 2009-10 trials, respectively; compared to $0.3 \pm 0.1 \%$ and $1.0 \pm 0.2 \%$ for noninoculated bulbs in 2008-09 and 2009-10, respectively; and $0.8 \pm 0.2 \%$ and $1.3 \pm 0.2 \%$ for bulbs injected with sterile water in 2008-09 and 2009-10, respectively (Table 1). The incidence of natural infection of each of the four bulb lots from the grower-cooperators' crops was very low as demonstrated by the noninoculated bulbs $(0.5 \pm 0.2 \%$ and $3.9 \pm 1.0 \%$ in $2008-$ 09 and 2009-10, respectively) (Table 1). Injection of bulbs with sterile water increased the incidence of bulb rot slightly $(5.8 \pm 1.0 \%$ and $6.1 \pm 1.0 \%$ in $2008-09$ and 2009-10, respectively), but far less than that of bulbs injected with E. cloacae $(92.8 \pm 1.1 \%$ and $92.3 \pm 1.2 \%$, respectively) (Table 1).

Table 1. Incidence and severity of Enterobacter bulb decay for bulbs of the onion cultivars Redwing and Vaquero harvested from crops grown in Washington State in 2008-09 and 2009-10, inoculated with Enterobacter cloacae, and subjected to different postharvest curing parameters

\begin{tabular}{lcc}
\hline $\begin{array}{l}\text { Trial and inoculation } \\
\text { treatment }\end{array}$ & $\begin{array}{c}\text { Mean } \pm \text { standard error of the } \\
\text { incidence }(\%) \text { of bulbs with } \\
\text { Enterobacter bulb decay }\end{array}$ & $\begin{array}{c}\text { Mean } \pm \text { standard error of } \\
\text { the severity of Enterobacter } \\
\text { bulb decay (min - max) }\end{array}$ \\
\hline $\begin{array}{l}\text { 2008-09 } \\
\text { Inoculated with } E \text {. cloacae }\end{array}$ & $92.8 \pm 1.1^{\mathrm{b}}$ & $15.3 \pm 0.6(0-100)$ \\
Inoculated with sterile water & $5.8 \pm 1.0$ & $0.8 \pm 0.2(0-90)$ \\
Noninoculated & $0.5 \pm 0.2$ & $0.3 \pm 0.1(0-80)$ \\
2009-10 & $92.3 \pm 1.2$ & $23.3 \pm 0.8(0-100)$ \\
Inoculated with $E$. cloacae & $6.1 \pm 1.0$ & $1.3 \pm 0.2(0-100)$ \\
Inoculated with sterile water & $3.9 \pm 1.0$ & $1.0 \pm 0.2(0-90)$ \\
Noninoculated & & \\
a Each bulb was cut down the center from neck to basal plate, through the inoculation site. Severity of \\
bulb rot was rated visually as percentage of cut surface area of fleshy scales showing symptoms of \\
Enterobacter bulb decay. Incidence was rated as percentage of bulbs with symptoms of this disease. \\
b Each value was calculated based on four replications of five bulbs for each of four postharvest curing \\
temperatures, two curing durations, three durations of storage, and two cultivars.
\end{tabular}

2008-09 trial. In the 2008-09 storage trial, the main effects of cultivar $(P=$ $0.005)$, curing temperature $(P<0.0001)$, curing duration $(P=0.0023)$, and duration of storage $(P<0.0001)$ were significant for severity of Enterobacter bulb decay for bulbs inoculated with E. cloacae. Significant two-way interactions occurred for cultivar and curing temperature $(P<$ $0.0001)$, cultivar and duration of storage $(P$ $=0.0055)$, curing temperature and curing duration $(P<0.0001)$, and curing temperature and duration of storage $(P<0.0001)$, as well as a significant three-way interaction between cultivar, curing temperature, and curing duration $(P=0.0084)$. Overall, inoculated Redwing bulbs exhibited significantly less severe bulb rot $(10.6 \%)$ than inoculated Vaquero bulbs (19.9\%). Curing the inoculated bulbs at $40^{\circ} \mathrm{C}$ resulted in significantly more severe bulb rot $(29.2 \%)$ than curing at 25,30 , or $35^{\circ} \mathrm{C}$ (10.6 to $10.7 \%$ ). Similarly, bulbs cured for 14 days developed significantly more severe rot $(19.1 \%)$ than bulbs cured for 2 days (11.4\%). Inoculated bulbs stored for 1 or 2 months after curing did not differ significantly in severity of bulb rot (12.4 to $14.0 \%$ ), but bulb rot was significantly more severe for bulbs stored for 3 months after curing (19.3\%).

Separate ANOVA were calculated for each cultivar at each curing duration and duration of storage because of significant two-way and three-way interactions for bulb rot severity ratings in the 2008-09 trial (Table 2, Fig. 2). When onion bulbs inoculated with $E$. cloacae were cured for 2 days, severity of bulb rot did not differ significantly among curing temperatures for either Redwing or Vaquero, regardless of storage duration (Fig. 2A, C, and E,

Table 2. Analyses of variance (ANOVAs) for severity of Enterobacter bulb decay of onion cultivars Redwing and Vaquero in a 2008-09 storage trial and a 2009-10 storage trial ${ }^{\mathrm{a}}$

\begin{tabular}{|c|c|c|c|c|c|c|}
\hline \multirow[b]{3}{*}{ ANOVA factor } & \multicolumn{3}{|c|}{ 2008-09 } & \multicolumn{3}{|c|}{ 2009-10 } \\
\hline & \multicolumn{3}{|c|}{ Duration of storage at $5^{\circ} \mathrm{C}$} & \multicolumn{3}{|c|}{ Duration of storage at $5^{\circ} \mathrm{C}$} \\
\hline & 1 month & 2 months & 3 months & 1 month & 2 months & 3 months \\
\hline \multicolumn{7}{|l|}{2 days of bulb curing } \\
\hline Curing temperature & 0.8483 & 0.0825 & 0.1568 & $0.0026 * * \mathrm{~b}$ & $0.0059 * *$ & $0.0018 * *$ \\
\hline Cultivar & $<0.0001 * *$ & $0.0105 *$ & 0.1270 & $0.0002 * *$ & $0.0060 * *$ & $0.0337 *$ \\
\hline Temperature-by-cultivar interaction & 0.0993 & 0.8087 & 0.1276 & 0.1650 & 0.7191 & $0.0159 *$ \\
\hline$R^{2}$ & 0.3410 & 0.2982 & 0.1907 & 0.5586 & 0.5056 & 0.5321 \\
\hline $\mathrm{CV}$ & 18.17 & 16.85 & 20.44 & 13.03 & 16.79 & 19.46 \\
\hline Transformation & $\log$ & $\log$ & Square rt & $\log$ & Square rt & Square rt \\
\hline \multicolumn{7}{|l|}{14 days of bulb curing } \\
\hline Curing temperature & $<0.0001 * *$ & $<0.0001 * *$ & $0.0005 * *$ & $<0.0001 * *$ & $<0.0001 * *$ & $<0.0001 * *$ \\
\hline Cultivar & $0.0012 * *$ & $0.0176 *$ & $0.0049 * *$ & $0.0466 *$ & $0.0334 *$ & 0.0711 \\
\hline Temperature-by-cultivar interaction & $<0.0001 * *$ & $<0.0001 * *$ & $0.0009 * *$ & 0.9445 & 0.8907 & 0.3672 \\
\hline$R^{2}$ & 0.6548 & 0.6122 & 0.4518 & 0.7646 & 0.8559 & 0.7884 \\
\hline $\mathrm{CV}$ & 16.42 & 20.12 & 17.98 & 15.95 & 16.94 & 18.90 \\
\hline Transformation & $\log$ & $\log$ & $\log$ & $\log$ & Square rt & Square rt \\
\hline
\end{tabular}

a A 0.5-ml suspension of Enterobacter cloacae $\left(10^{8} \mathrm{CFU} / \mathrm{ml}\right)$ was injected into the shoulder of each onion bulb immediately after harvest. Bulbs were cured at temperatures ranging from 25 to $40^{\circ} \mathrm{C}$ for 2 or 14 days, then stored at $5^{\circ} \mathrm{C}$ for 1,2 , or 3 months. Four replications of five onion bulbs were inoculated per treatment combination per year. Onion bulbs were harvested from commercial crops of Redwing and Vaquero grown in the semi-arid Columbia Basin of central Washington by a different grower-cooperator each year. Bulbs used in the 2008-09 trial and the 2009-10 trial were produced under center-pivot and drip irrigation, respectively.

b $*$ and $* *=$ significant at $P=0.05$ and $P=0.01$, respectively. $R^{2}=$ coefficient of determination. $\mathrm{CV}=$ coefficient of variance. Transformation $=$ original data was subjected to $\log$ or square root (square rt) transformation because of heterogeneous variances and/or non-normal distribution of residuals in the ANOVA. 
respectively). However, when the duration of curing was increased to 14 days, bulbs cured at $40^{\circ} \mathrm{C}$ developed significantly more severe rot than bulbs cured at 25,30 , or $35^{\circ} \mathrm{C}$, with no significant differences in severity ratings at the three lower curing temperatures. This was observed for both Redwing and Vaquero regardless of the storage duration. However, the magnitude of increase in severity of bulb rot from 35 to $40^{\circ} \mathrm{C}$ curing temperatures was greater for Vaquero than Redwing at each duration of storage (Fig. 2A, C, and E). Severity of bulb rot increased fourfold to ninefold (depending on the duration of storage) for Vaquero bulbs cured at $40^{\circ} \mathrm{C}$ compared to lower curing temperatures, whereas severity ratings only increased twofold to threefold for Redwing.

2009-10 trial. In the 2009-10 storage trial, the main effects of cultivar $(P=$ 0.0043), curing temperature $(P<0.0001)$, curing duration $(P=0.0003)$, and duration of storage $(P<0.0001)$ were significant for severity of Enterobacter bulb decay for bulbs inoculated with E. cloacae. Significant two-way interactions occurred be- tween cultivar and curing temperature $(P=$ $0.04)$, cultivar and duration of storage $(P=$ $0.0059)$, and curing temperature and curing duration $(P<0.0001)$. The two-way interaction between curing temperature and duration of storage was not significant, and the three-way interactions were not significant (data not shown). Overall, bulb rot severity ratings were more severe in the 2009-10 trial than in the 2008-09 trial. Inoculated Redwing bulbs exhibited significantly less severe bulb rot (19.7\%) than inoculated Vaquero bulbs $(27.0 \%)$. Curing inoculated bulbs at $40^{\circ} \mathrm{C}$ resulted in significantly more severe bulb rot $(51.2 \%)$ than curing at $35^{\circ} \mathrm{C}(16.5 \%)$, which in turn resulted in more severe bulb rot than curing at 25 or $30^{\circ} \mathrm{C}(13.4$ and $12.0 \%$, respectively). Bulbs cured for 14 days showed significantly more severe bulb rot $(32.6 \%)$ than bulbs cured for 2 days $(14.1 \%)$. Similarly, the longer the duration of storage, the more severe the bulb rot $(17.8,24.6$, and $27.7 \%$ for bulbs stored 1,2 , or 3 months after curing, respectively).

As in the 2008-09 trial, significant twoway interactions for bulb rot severity rat-

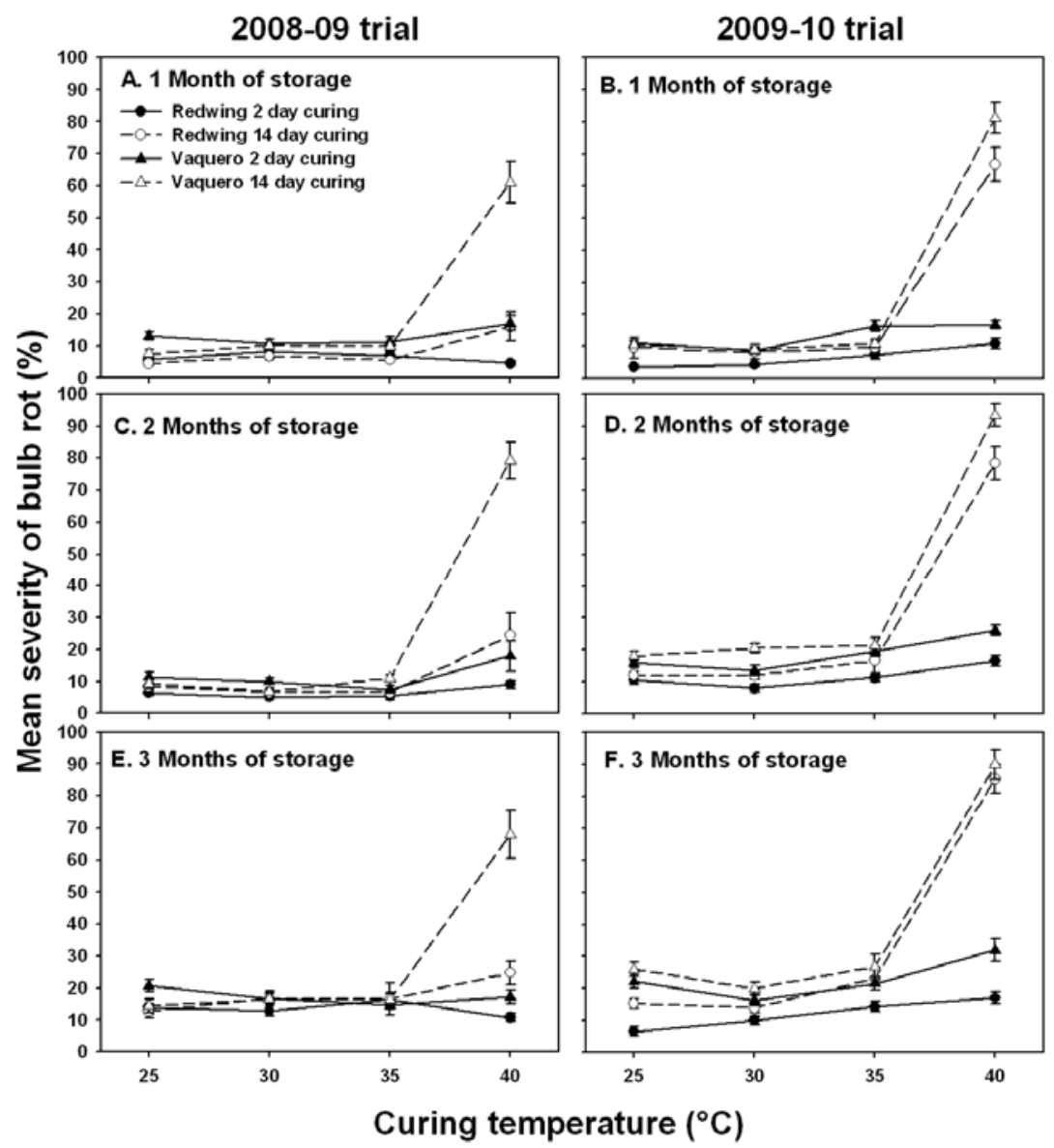

Fig. 2. Mean severity of onion bulb rot caused by Enterobacter cloacae in storage trials in 2008-09 (A, C, and E) and 2009-10 (B, D, and F) with the cultivars Redwing and Vaquero. Each bulb was inoculated with E. cloacae (as described in the text), cured at $25,30,35$, or $40^{\circ} \mathrm{C}$ for 2 or 14 days, and then stored at $5^{\circ} \mathrm{C}$ for 1 month (A and B), 2 months ( $\mathbf{C}$ and D), or 3 months (E and F). Each bulb was then cut down the center from the neck to the basal plate through the injection site on the shoulder of the bulb, to assess severity of bulb rot (percentage of the cut surface area of fleshy scales exhibiting symptoms of Enterobacter bulb decay). Each data point shows the mean and standard error of the severity of bulb rot for four replications of five bulbs. ings led to calculation of a separate ANOVA for each cultivar at each curing duration and each duration of storage (Table 2, Fig. 2). Inoculated onion bulbs cured for 2 days had the least severe bulb rot, with no significant difference among bulbs cured at 25 or $30^{\circ} \mathrm{C}$ for either Redwing or Vaquero, regardless of how long bulbs were stored (Fig. 2B, D, and F). However, for both cultivars, bulb rot was significantly more severe when curing temperatures of 35 or $40^{\circ} \mathrm{C}$ were used and the bulbs stored for 1 month (Fig. 2B). When bulbs were stored for 2 or 3 months, bulb rot was significantly more severe for both cultivars with a curing temperature of $40^{\circ} \mathrm{C}$ compared to $35^{\circ} \mathrm{C}$ (Fig. $2 \mathrm{D}$ and F). When the duration of curing was increased to 14 days, bulbs cured at $40^{\circ} \mathrm{C}$ had significantly more severe rot than bulbs cured at 25,30 , or $35^{\circ} \mathrm{C}$, with no significant difference in severity ratings among the three lower curing temperatures. This was observed for both Redwing and Vaquero regardless of storage duration. The magnitude of increase in severity of bulb rot caused by the highest curing temperature was slightly greater for Vaquero than Redwing in bulbs stored for 1 or 2 months (Fig. 2B and D), but not in bulbs stored for 3 months (Fig. 2F).

Correlation coefficients. For onion bulbs inoculated with E. cloacae, the correlation of mean bulb rot severity ratings in the 2008-09 trial versus the 2009-10 trial was highly significant when calculated across both cultivars $(r=0.78$ at $P<$ $0.0001)$, or separately by cultivar $(r=0.64$ at $P<0.0001$ for Redwing; and $r=0.92$ at $P<0.0001$ for Vaquero) (Fig. 3), demonstrating relative consistency in reaction of bulbs of these two cultivars to the postharvest curing parameters and durations of storage evaluated.

\section{DISCUSSION}

Enterobacter bulb decay is a relatively newly described bacterial storage disease of onion, and little is known about how production practices might affect development of this disease in storage $(8,21)$. In this study, we evaluated several parameters that onion growers have the capacity to manipulate during postharvest curing and storage, to assess the impact of these parameters on severity of Enterobacter bulb decay for two onion cultivars, Redwing and Vaquero, commonly grown in the semi-arid Pacific Northwest region of the United States. The bulbs were inoculated with E. cloacae, subjected to curing temperatures ranging from 25 to $40^{\circ} \mathrm{C}$ for 2 or 14 days, and stored for 1,2 , or 3 months at $5^{\circ} \mathrm{C}$. Each of these curing parameters and the duration of storage significantly impacted severity of Enterobacter bulb rot in both trials, regardless of environmental conditions and cultural practices under which the commercial onion crops were grown and from which the bulbs used in 
this study were harvested (e.g., centerpivot irrigation for the 2008-09 crops versus drip irrigation for the 2009-10 crops).

Field and postharvest curing procedures are critical in the preparation of onion bulbs for long-term storage (3). Curing is used to produce strong, dry, outer wrapper skins that prevent shrinkage, and to dry the necks of onion bulbs in order to reduce the risk of fungal pathogens infecting fleshy bulb scales during storage $(3,5)$. In this study, the temperatures at which onion bulbs were cured exhibited a significant effect on severity of Enterobacter bulb decay. The most severe bulb rot was observed when bulbs were cured at the highest temperature $\left(40^{\circ} \mathrm{C}\right.$ versus 25 to $\left.35^{\circ} \mathrm{C}\right)$ prior to cold storage. This effect was exacerbated by a longer curing duration (14 versus 2 days) and the longer the bulbs were stored after curing ( 3 versus 1 or 2 months). When inoculated onion bulbs were subjected to a shorter duration of curing ( 2 versus 14 days), the severity of bulb rot did not differ among curing temperatures as long as curing temperature was $\leq 35^{\circ} \mathrm{C}$. This suggests that the exact curing temperature may not be as critical for management of Enterobacter bulb decay if the duration of curing is relatively short and curing temperature is $\leq 35^{\circ} \mathrm{C}$. This was not surprising given that E. cloacae grows well at $40^{\circ} \mathrm{C}(15)$. Therefore, if E. cloacae is present in onion bulbs at harvest, postharvest curing at temperatures $>35^{\circ} \mathrm{C}$ is likely to increase the risk of Enterobacter bulb decay. The results suggest that curing onion bulbs at 25 to $35^{\circ} \mathrm{C}$ for longer than 2 days could produce the desired tight wrapper skins and dried necks without promoting development of Enterobacter bulb decay in bulbs latently infected with $E$. cloacae.

In this study, onion bulbs of the cultivar Redwing developed significantly less severe Enterobacter bulb decay than bulbs of the cultivar Vaquero. This supports previous observations of Schroeder et al. (19), who evaluated onion storage cultivars for resistance to E. cloacae. In both years of that study, Redwing bulbs inoculated with E. cloacae at harvest and stored in a commercial storage facility for up to 4 months exhibited less severe bulb rot than Vaquero bulbs. Together, these studies demonstrate consistency in relative susceptibility of the two cultivars to E. cloacae, regardless of growing conditions of the crops from which the bulbs were harvested or the postharvest curing parameters evaluated. Several factors that could potentially influence Enterobacter bulb decay in storage were not controlled in either of these studies, including crop production practices and field curing conditions (3). In both years of this study, the onion crops were grown in the semi-arid Columbia Basin of central Washington on relatively fine, sandy loam soils. However, bulbs used in the 2008-09 trial were harvested from crops under center-pivot irrigation, whereas bulbs in the 2009-10 trial were harvested from crops grown with drip irrigation. Although empirical evidence from growers suggests the incidence of bacterial storage rots is typically greater for onion crops grown under overhead irrigation systems, the incidence of bacterial storage rots in the noninoculated bulbs in this study was slightly greater for bulbs harvested from the drip irrigated crops (3.9 $\pm 1.0 \%)$ than from the center-pivot irrigated crops $(0.5 \pm 0.2 \%)$. The potential effects of the type of irrigation system on Enterobacter bulb decay were confounded with location, environmental conditions, and other production practices of each crop and season, e.g., fertilizer program, timing of the final irrigation prior to field curing, and environmental conditions during field curing (3). This suggests further research is warranted to investigate the potential effects of center-pivot versus drip irrigation on development of Enterobacter bulb decay.

Injection of sterile water into an onion bulb can increase the incidence or severity of bacterial storage rots $(7,18-20)$. In this study, $5.8 \pm 1.0 \%$ of the bulbs injected with sterile water in the 2008-09 trial exhibited symptoms of bacterial storage rots compared to $6.1 \pm 1.0 \%$ of the bulbs injected with sterile water in the 2009-10 trial. In both trials, the incidence of bulbs with symptoms of bacterial storage rot was greater for bulbs injected with water compared to the noninoculated bulbs. Although the injection method used in this study could potentially introduce microorganisms from the surface of the bulb into the fleshy scales at the site of injection, the injection site was surface-sterilized with alcohol immediately prior to injection, reducing the potential for such contamination. Therefore, injection of sterile water into the fleshy scales of Redwing and Vaquero bulbs may have induced endophytic bacteria and/or latent infections present in the bulbs at harvest to become active during curing and storage. A similar effect was observed for four of 39 onion cultivars screened by Schroeder et al. (19) for resistance to E. cloacae using the same inoculation method. In that study, although the cultivars with red bulbs had significantly less severe bulb rot caused by E. cloacae than the white and yellow cultivars, the bulbs of four cultivars (OLYX05-26, REE, Redwing, and Talon) injected with water developed significant levels of storage rot from which bacteria other than E. cloacae were isolated. Natural, latent infection of bulbs of these four cultivars may have been triggered to become active as a result of injecting water into the bulbs.

Spraying inoculum of E. cloacae onto onion plants in the field prior to implementing specific cultural practices or treatments, including field and postharvest curing practices, would have provided a more natural method of inoculation than the bulb injection method used in this study. However, a spray application of inoculum would not have been appropriate since $E$. cloacae is an opportunistic human pathogen $(6,16)$, and inoculating growercooperator onion crops could have posed food safety risks. Inoculating E. cloacae into onion bulbs by injection after the bulbs were removed from the field pro-

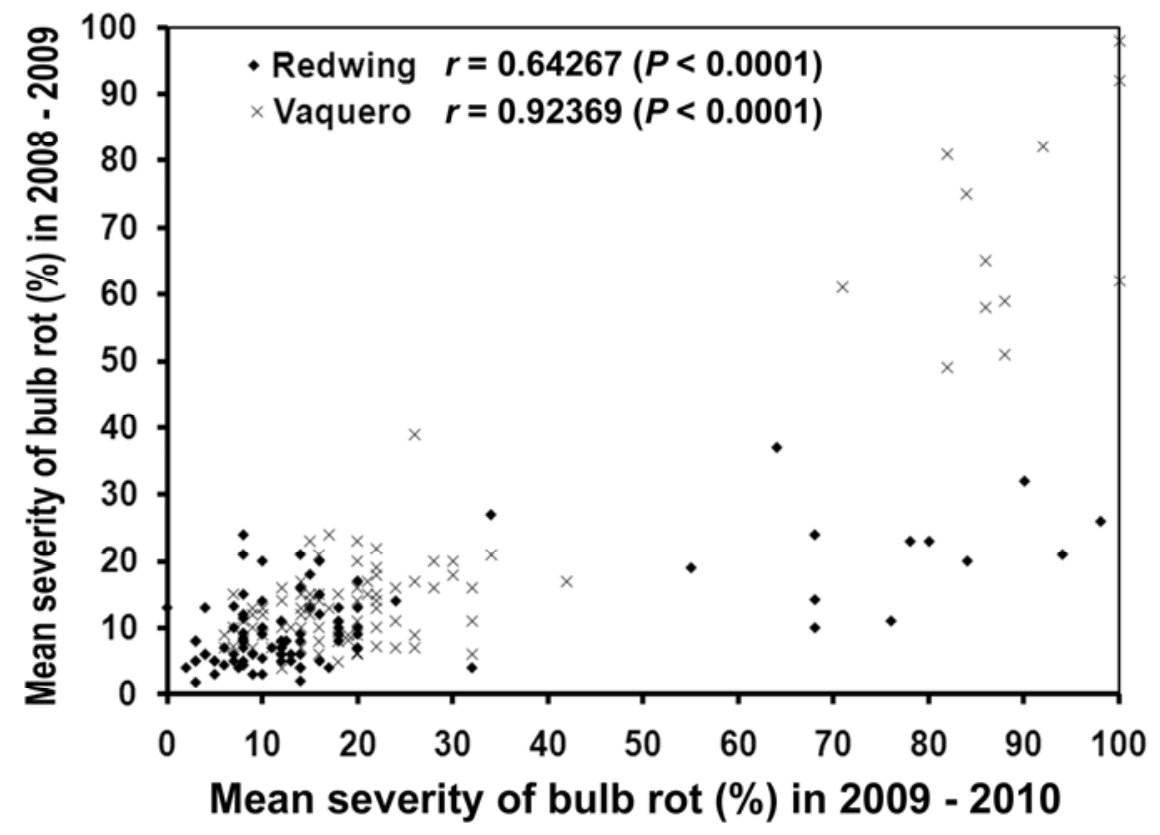

Fig. 3. Correlation coefficients for mean severity of Enterobacter bulb decay in a 2008-09 trial versus a 2009-10 trial for bulbs of the onion cultivars Redwing and Vaquero inoculated with Enterobacter cloacae at harvest and then subjected to four curing temperatures, two curing durations, and three durations of storage (refer to the main text for details). Each data point is the mean of four replications of five bulbs. 
vided a cost-effective and efficient manner of evaluating Enterobacter bulb decay, as demonstrated previously (18-20). The results of this study illustrate the potential impact of postharvest curing parameters on development of Enterobacter bulb decay in storage, and demonstrate how onion growers might manipulate postharvest curing temperature, curing duration, and/or duration of storage in order to reduce the risk of Enterobacter bulb decay in storage.

\section{ACKNOWLEDGMENTS}

We gratefully acknowledge financial support for this project from the Pacific Northwest Vegetable Association, the Washington State Commission for Pesticide Registration, and a 2006-07 Washington State University New Faculty Seed Grant. Invaluable in-kind support was provided by Carr Farms and $\mathrm{L} \& \mathrm{~L}$ Ag Production in the form of onion bulbs for storage evaluations. Special thanks to Jodi Humann, Mark Mazzola, Timothy Murray, and Dennis Johnson for critical review of the manuscript prior to submission. In addition, invaluable technical support was provided by Jenette Anderson, Juan Pena, Cathy Merritt, Sarah Dossey, and Nathan Peterson. This project was supported by the Department of Plant Pathology (PPNS No. 0547) in the Washington State University College of Agricultural, Human and Natural Resource Sciences, and the Washington State University Agricultural Research Center for CRIS Project No. WNPOO652.

\section{LITERATURE CITED}

1. Anonymous. 2004-2008. Agricultural prices for onions. Online. http://www.nass.usda.gov/ QuickStats/

2. Bishop, A. L., and Davis, R. M. 1990. Internal decay of onions caused by Enterobacter cloacae. Plant Dis. 74:692-694.

3. Brewster, J. L. 2006. Onions and Other Vegetable Alliums. Crop Production Science in Horticulture Series No. 3. CAB International, Wallingford, UK

4. Ceponis, M. J., Cappellini, R. A., and Lightner, G. W. 1986. Disorders in onion shipments to the New York market, 1972-1984. Plant Dis. 70:988-991.

5. Chilvers, M. I., and du Toit, L. J. 2006. Detection and identification of Botrytis species associated with neck rot, scape blight, and umbel blight of onion. Online. Plant Health Progress
doi:10.1094/PHP-2006-1127-01-DG.

6. Clementino, M. M., de Filippis, I., Nascimento, C. R., Branquinho, R., Rocha, C. L., and Martins, O. B. 2001. PCR analyses of tRNA intergenic spacer, 16S-23S internal transcribed spacer, and randomly amplified polymorphic DNA reveal inter- and intraspecific relationships of Enterobacter cloacae strains. J. Clin. Microbiol. 39:3865-3870.

7. Cother, E. J., and Dowling, V. 1986. Bacteria associated with internal breakdown of onion bulbs and their possible role in disease expression. Plant Pathol. 35:329-336.

8. Gent, D. H. 2008. Enterobacter bulb decay. Pages 67-68 in: Compendium of Onion and Garlic Diseases and Pests, 2nd ed. H. F. Schwartz and S. K. Mohan, eds. American Phytopathological Society, St. Paul, MN.

9. Jang, E. B., and Nishijima, K. A. 1990. Identification and attractancy of bacteria associated with Dacus dorsalis (Diptera, Tephritidae). Environ. Entomol. 19:1726-1731.

10. Marchini, D., Rosetto, M. Dallai, R and Marri, L. 2002. Bacteria associated with the oesophageal bulb of the medfly Ceratitis capitata (Diptera: Tephritidae). Curr. Microbiol. 44:120-124.

11. Nishijima, K. A., Alvarez, A. M., Hepperly, P. R., Shintaku, M. H., Keith, L. M., Sato, D. M., Bushe, B. C., Armstrong, J. W., and Zee, F. T. 2004. Association of Enterobacter cloacae with rhizome rot of edible ginger in Hawaii. Plant Dis. 88:1318-1327.

12. Nishijima, K. A., Couey, H. M., and Alvarez, A. M. 1987. Internal yellowing, a bacterial disease of papaya fruits caused by Enterobacter cloacae. Plant Dis. 71:1029-1034.

13. Nishijima, K. A., Wall, M. M., and Siderhurst, M. S. 2007. Demonstrating pathogenicity of Enterobacter cloacae on macadamia and identifying associated volatiles of gray kernel of macadamia in Hawaii. Plant Dis. 91:12211228.

14. Pelter, G. Q., and Sorensen, E. J. 2004. Crop profile for onions in Washington. U.S. Dep. Agric. National Information System Pest Management Center.

15. Richard, C. 1984. Genus VI Enterobacter Hormaeche and Edwards 1960, 72; Nom. Cons. Opin. 28, Jud. Comm. 1963, 38. Pages 465-469 in: Bergey's Manual of Systematic Bacteriology. Vol. I. N. R. Kreig and J. G. Holt, eds. Williams \& Wilkins, Baltimore, MD
16. Sanders, W. E., and Sanders, C. C. 1997. Enterobacter spp.: Pathogens poised to flourish at the turn of the century. Clin. Microbiol. Rev. 10:220-241.

17. Schroeder, B. K., du Toit, L. J., and Schwartz, H. F. 2009. First report of Enterobacter cloacae causing onion bulb rot in the Columbia Basin of Washington State. Plant Dis. 93:323.

18. Schroeder, B. K., Waters, T., and du Toit, L. J. 2008. Evaluation of onion cultivars for resistance to Enterobacter cloacae in storage, 2007-2008. Plant Dis. Manage. Rep. 2:V159. Online. DOI:10.1094/PDMR02.

19. Schroeder, B. K., Waters, T., and du Toit, L. J. 2010. Evaluation of onion cultivars for resistance to Enterobacter cloacae in storage. Plant Dis. 94:236-243.

20. Schroeder, B. K., Waters, T., Wohleb, C., and du Toit, L. J. 2009. Evaluation of onion cultivars for resistance to Enterobacter cloacae in storage, 2008-2009. Plant Dis. Manage. Rep. 3:V142. Online. DOI:10.1094/PDMR03

21. Schwartz, H. F. and Mohan, S. K. 2008. Compendium of Onion and Garlic Diseases and Pests, 2nd ed. American Phytopathological Society, St. Paul, MN.

22. Schwartz, H. F., and Otto, K. 2000. First report of a bulb decay of onion by Enterobacter cloacae in Colorado. Plant Dis. 84:808.

23. Vidaver, A. K. 1967. Synthetic and complex media for the rapid detection of fluorescence of phytopathogenic pseudomonads: Effect of the carbon source. Appl. Microbiol. 15:1523 1524

24. Wright, P. J., and Grant, D. G. 1997. Effects of cultural practices at harvest on onion bulb quality and incidence of rots in storage. N.Z. J. Crop Hortic. Sci. 25:353-358

25. Wright, P. J., Grant, D. G., and Triggs, C. M. 2001. Effects of onion (Allium cepa) plant maturity at harvest and method of topping on bulb quality and incidence of rots in storage. N.Z. J. Crop Hortic. Sci. 29:85-91.

26. Wright, P. J., Hale, C. N., and Fullerton, R. A. 1993. Effect of husbandry practices and water applications during field curing on the incidence of bacterial soft-rot of onions in store N.Z. J. Crop Hortic. Sci. 21:161-164.

27. Wright, P. J., and Triggs, C. M. 2005. Effects of curing, moisture, leaf removal, and artificial inoculation with soft-rotting bacteria on the incidence of bacterial soft rot of onion (Allium cepa) bulbs in storage. Australas. Plant Pathol. 34:355-359. 